Monika Staniszewska

ORCID: 0000-0003-3186-8788

Uniwersytet Łódzki

\title{
Ubóstwo energetyczne jako problem społeczny i sposoby jego rozwiązywania
}

\author{
DOI: $10.19195 / 1643-0328.25 .3$
}

Słowa kluczowe: ubóstwo energetyczne, odbiorca wrażliwy, energetyka

\section{Wprowadzenie}

Ubóstwo energetyczne jest zjawiskiem społecznym dotyczącym coraz większej liczby osób. Z problemem tym borykają się zarówno najbiedniejsze kraje Afryki, kraje rozwijające się w Azji, na Bliskim Wschodzie i w Ameryce Łacińskiej, jak i kraje Europy. Oczywiście warto zwrócić uwagę na jego zróżnicowane przyczyny. Ubóstwo energetyczne w krajach Trzeciego Świata wiąże się z brakiem dostępu do energii elektrycznej. W krajach lepiej rozwiniętych, w tym w Polsce, problem ten jest efektem kosztów energii w stosunku do dochodów, jakimi dysponują gospodarstwa domowe. Ograniczenia lub brak dostępu do energii wiążą się z konsekwencjami dla zdrowia i komfortu życia człowieka, a także wpływają na możliwości jego rozwoju i korzystania z osiągnięć cywilizacyjnych. Ubóstwo energetyczne jest traktowane jako jeden z problemów społecznych. Jest zjawiskiem wieloaspektowym, dotykającym kwestii ekonomii, zdrowia, spraw społecznych.

\section{Definicje ubóstwa energetycznego oraz jego przyczyny i skutki}

Pierwszym krajem europejskim, który dostrzegł problem ubóstwa energetycznego i zapoczątkował badania w tym obszarze (już w latach 80 . XX w.), była Wielka Brytania. Impulsem była obserwacja dotycząca zwiększonej liczby zgonów w okresie zimowym (liczba zgonów na skutek powikłań pochorobowych, mających swoją przyczynę w niedogrzaniu, była tu najwyższa spośród wszystkich krajów Europy Zachodniej). Wskazane zostały także grupy społeczne, które są najbardziej zagrożone ubóstwem energetycznym, tj.: młode pary i pary w starszym wieku, pary z niesamodzielnym dzieckiem lub dziećmi, 
rodzice samotnie wychowujący potomstwo, gospodarstwa wieloosobowe i jednoosobowe (szczególnie osoby starsze), a także mniejszości etniczne ${ }^{1}$.

W Wielkiej Brytanii wypracowano także definicję ,ubóstwa energetycznego” (ang. fuel poverty). Pierwsza z nich pojawiła się w $2001 \mathrm{r}$. w dokumentach rządowych i wyznacza próg dochodów przeznaczanych na wydatki związane z energetyką ${ }^{2}$. Gospodarstwo domowe, które przeznacza ponad $10 \%$ swojego dochodu na utrzymanie dostatecznego poziomu ogrzewania $\left(\mathrm{tj} .21^{\circ} \mathrm{C}\right.$ w głównych pomieszczeniach mieszkalnych oraz $18^{\circ} \mathrm{C}$ w pozostałych pomieszczeniach) znajduje się w sytuacji ubóstwa energetycznego. Definicja ta została rozszerzona także o kategorie wykraczające poza ciepłownictwo, uwzględniając m.in.: podgrzewanie wody, oświetlenie, stosowanie urządzeń elektrycznych oraz gotowanie. Brytyjczycy określili również wskaźniki wyznaczające ubóstwo energetyczne, czyli: wydajność energetyczną budynku, cenę energii oraz poziom dochodu w gospodarstwie domowym ${ }^{3}$.

W polskim prawodawstwie i naukach społecznych problem ubóstwa energetycznego został dostrzeżony niedawno. Jedną z definicji tego zjawiska zaproponowali Dominik Owczarek i Agata Miazga, wskazując, iż jest to

zjawisko polegające na doświadczaniu trudności w zaspokojeniu podstawowych potrzeb energetycznych w miejscu zamieszkania za rozsądną cenę, na którą składa się utrzymanie adekwatnego standardu ciepła i zaopatrzenie w pozostałe rodzaje energii służące zaspokojeniu w adekwatny sposób podstawowych potrzeb funkcjonowania biologicznego i społecznego członków gospodarstwa domowego ${ }^{4}$.

Ubóstwo energetyczne, podobnie jak ekonomiczne, może być rozpatrywane w perspektywie absolutnej lub relatywnej. Obydwie te koncepcje bazują na podejściu obiektywnym. Absolutną miarą ubóstwa energetycznego jest stosunek dochodu gospodarstwa domowego do jego wydatków na cele energetyczne. Zgodnie $\mathrm{z}$ angielskimi założeniami przyjmuje się próg $10 \%$. Jednakże, jak wskazują Owczarek i Miazga ${ }^{5}$, w polskich realiach próg dziesięcioprocentowy jest nieadekwatny i proponują przyjęcie progu $13 \%$. Relatywną miarą ubóstwa energetycznego, opartą na brytyjskiej definicji Low Income, High Costs (LIHC), jest zestawienie wydatków energetycznych oraz dochodów gospodarstwa domowego $\mathrm{z}$ wydatkami/dochodami innych gospodarstw (na podstawie mediany poziomów w danej populacji). Podejście to wymaga spełnienia dwóch warunków:

- wysokie wydatki energetyczne (High Costs),

- niskie dochody (Low Income) ${ }^{6}$.

1 I. Figaszewska, Ubóstwo energetyczne - co to jest?, „Biuletyn Urzędu Regulacji Energetyki” 2009, nr 5, s. 2, http://www.cire.pl/pliki/2/UbostwoenergetyczneFig.pdf (dostęp: 3.04.2017).

${ }^{2}$ Cutting the cost of keeping warm. A fuel poverty strategy for England, 3 marca 2015, s. 14-15, http:// www.infrastructure-intelligence.com/sites/default/files/article_uploads/cutting_the_cost_of_keeping_ warm.pdf (dostęp: 4.04.2017).

3 The UK Fuel Poverty Strategy. 6th Annual Progress Report 2008. Fuel Poverty Statistics Annex, s. 40, http://webarchive.nationalarchives.gov.uk/+/http:/www.berr.gov.uk/files/file48036.pdf(dostęp: 4.04.2017).

4 D. Owczarek, A. Miazga, Ubóstwo energetyczne w Polsce - definicja i charakterystyka społeczna grupy, Warszawa 2015, s. 6.

5 Ibidem, s. 25-26.

6 A. Miazga, D. Owczarek, Dom zimny, dom ciemny - czyli ubóstwo energetyczne w Polsce, „IBS Working Paper" 2015, nr 16, s. 8-9, http://www.mpec.przemysl.pl/plugins/filemanager/userfiles/images/2015/ pub/ubenerg.pdf (dostęp: 10.04.2017). 
Podejście relatywne, oparte na LIHC, obowiązuje w Wielkiej Brytanii od $2012 \mathrm{r}$.

W literaturze przedmiotu istnieje także podejście subiektywne, bazujące na deklaracjach respondentów dotyczących dyskomfortu termicznego w mieszkaniach (problemów z utrzymaniem ciepła zimą i chłodu latem), jego zawilgocenia lub problemów związanych z opłacaniem rachunków za energię elektryczną, ciepło i gaz.

Jak wskazują autorzy ekspertyzy Propozycje mechanizmów wsparcia procesu przeciwdziałania zjawisku ubóstwa energetycznego $w$ Polsce ${ }^{7}$, można wskazać trzy przyczyny ubóstwa energetycznego:

1. problemy techniczne - związane są z niskim poziomem efektywności energetycznej budynku lub używaniem energochłonnych sprzętów, co przekłada się na wzrost wydatków na cele energetyczne;

2. problemy ekonomiczne - związane z niskim dochodem $\mathrm{w}$ danym gospodarstwie domowym;

3. postawa - związana z nieefektywnym wykorzystywaniem energii.

Rozwiązaniem wskazanych wyżej problemów są odpowiednio:

1. dla problemów technicznych - poprawa stanu budynków mieszkaniowych, przede wszystkim ich termomodernizacja i wymiana urządzeń na energooszczędne; Narodowy Fundusz Ochrony Środowiska i Gospodarki Wodnej (NFOŚiGW) uruchomił pilotażowy program Ryś - termomodernizacja budynków jednorodzinnych ${ }^{8}$ na lata 2015-2023 $\mathrm{z}$ budżetem $400 \mathrm{mln}$ zł; wsparcie to dedykowane jest osobom fizycznym, jednostkom samorządu terytorialnego oraz organizacjom pozarządowym; dofinansowanie może być przeznaczone na wykonanie prac termoizolacyjnych, modernizację instalacji wewnętrznych i wymianę źródeł ciepła (w tym instalacje odnawialnych źródeł energii);

2. dla problemów ekonomicznych - wsparcie finansowe gospodarstw domowych o najniższych dochodach; ten instrument, w postaci dodatku energetycznego, jest przyznawany w Polsce od 2014 r.;

3. dla postaw - działania edukacyjne i informacyjne, prowadzone na szeroką skalę i dotyczące m.in.: sposobów oszczędzania energii i obniżania rachunków za nią, sposobów dokonywania racjonalnych zakupów sprzętów RTV i AGD (z uwzględnieniem klasy energetycznej urządzeń), zmiany niewłaściwych nawyków związanych z wykorzystywaniem energii elektrycznej i cieplnej.

Prócz wskazanych w powyższym opracowaniu przyczyn ubóstwa energetycznego ważna jest także kwestia kosztów energii. Ceny energii elektrycznej w Polsce, w przeliczeniu na euro, należą do najniższych w Unii Europejskiej. W drugiej połowie $2015 \mathrm{r}$. gospodarstwo domowe w Polsce płaciło za $100 \mathrm{kWh}$ nieco ponad 14 euro. Jest to kwota niższa od średniej unijnej, która wynosiła 17,99 euro.

7 A. Węglarz, G. Kubalski, D. Owczarek, Propozycje mechanizmów wsparcia procesu przeciwdziałania zjawisku ubóstwa energetycznego w Polsce, Warszawa 2014, s. 8-9.

8 Szczegółowe informacje na temat programu Ryś - termomodernizacja budynków jednorodzinnych dostępne są na stronie internetowej Narodowego Funduszu Ochrony Środowiska i Gospodarki Wodnej: http://nfosigw.gov.pl/oferta-finansowania/srodki-krajowe/programy-priorytetowe/rys---termomodernizacja-budynko-jednorodzinnych/informacje-o-programie/. 


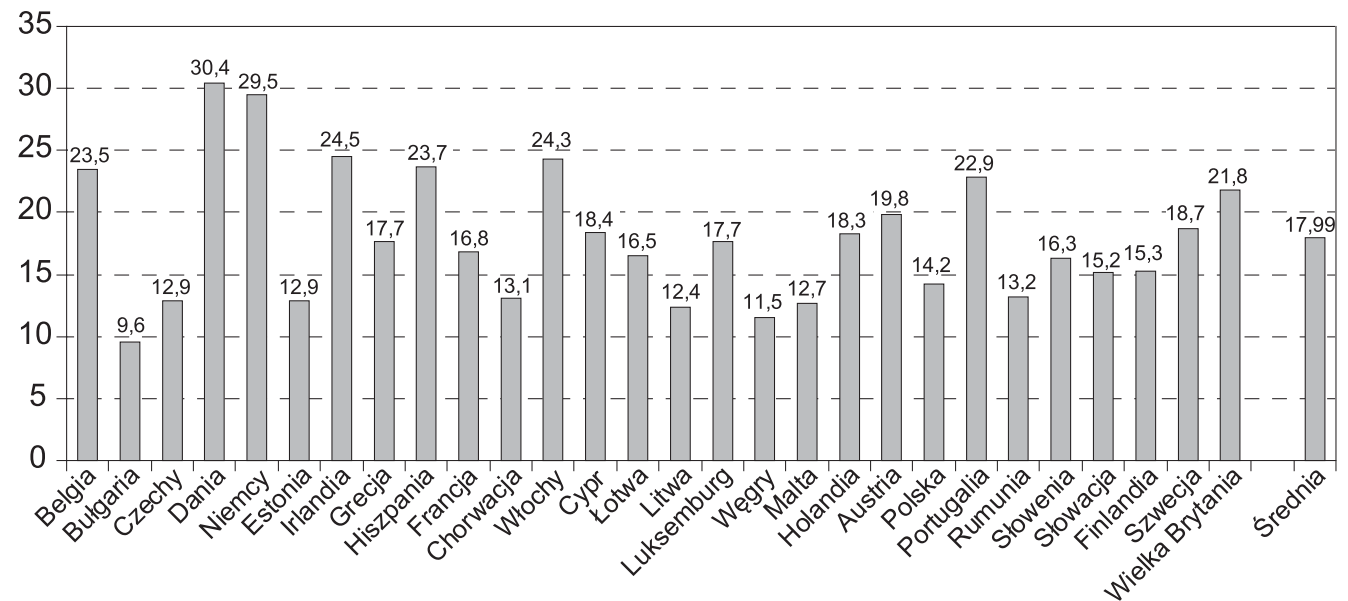

Rycina 1. Średnia cena za $100 \mathrm{kWh}$ w 2. połowie 2015 r. (w euro).

Źródło: opracowanie własne na podstawie danych Eurostat ${ }^{9}$.

Jednakże sytuacja ta ulega zasadniczej zmianie, jeżeli weźmie się pod uwagę ceny energii elektrycznej w przeliczeniu na parytet siły nabywczej, dający bardziej miarodajny obraz sytuacji, bo uwzględniający rzeczywistą siłę nabywczą mieszkańców danego kraju. W tym zestawieniu mieszkańcy Polski wypadają zdecydowanie gorzej - płacą za

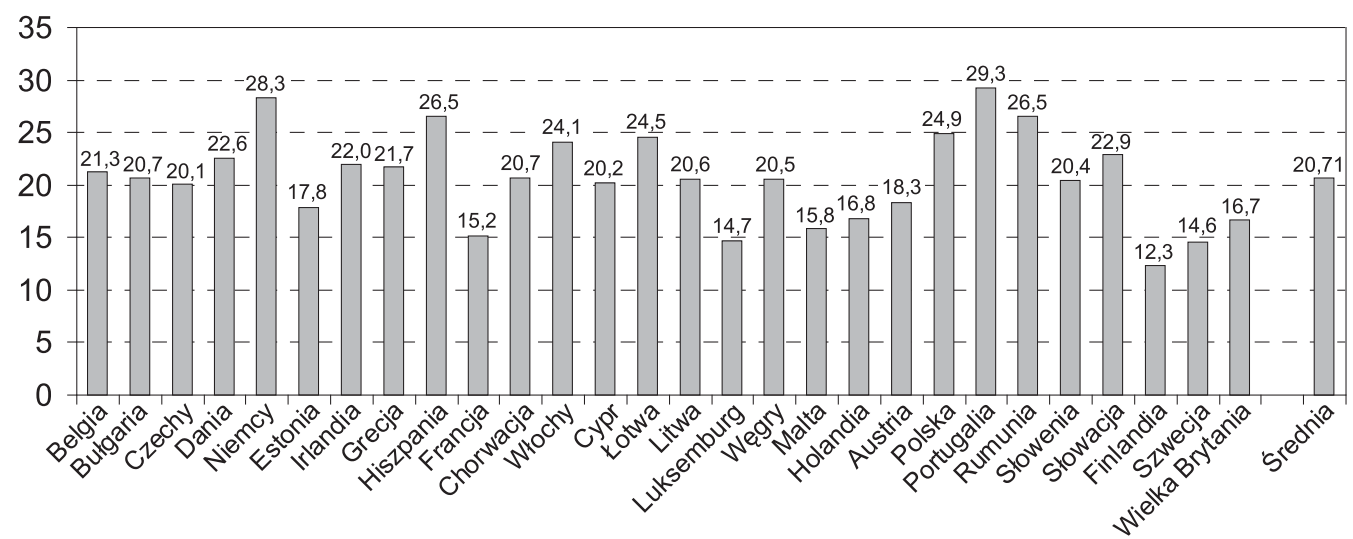

Rycina 2. Średnia cena za $100 \mathrm{kWh}$ w 2. połowie 2015 r. w przeliczeniu na parytet siły nabywczej (PPS).

Źródło: opracowanie własne na podstawie danych Eurostat ${ }^{10}$.

9 Eurostat Newsrelease, 103/2016 - 27 maja 2016, http://ec.europa.eu/eurostat/documents/2995521/ 7405554/8-27052016-AP-EN.pdf/b5652235-2df1-47ed-84c6-701614849b3a (dostęp: 12.04.2017).

10 Ibidem. 
energię elektryczną znacznie więcej niż średnia w krajach Unii Europejskiej. Za prąd od Polaków więcej płacą tylko mieszkańcy czterech unijnych krajów: Niemiec, Hiszpanii, Portugalii i Rumunii.

Brak komfortu termicznego wpływa negatywnie na zdrowie (zarówno fizyczne, jak i psychiczne) człowieka oraz na jego możliwości rozwoju (ograniczony dostęp do technologii cyfrowych). Niedogrzanie i zawilgocenie może także prowadzić do degradacji stanu technicznego samych budynków. W szerszym kontekście ubóstwo energetyczne może również wpływać na stan środowiska naturalnego - nieefektywne energetycznie mieszkania potrzebują większej ilości energii do ich ogrzania, a to może przekładać się na wzrost emisji dwutlenku węgla. Ponadto, aby zaoszczędzić na opale (zwłaszcza węglu), ludzie będący w trudnej sytuacji materialnej i posiadający domowe piece poszukują innych źródeł ciepła. Spalanie śmieci jest częstym procederem, który niekorzystnie wpływa na jakość powietrza.

Ubóstwo energetyczne jest realnym problemem, z którym boryka się wiele krajów na świecie, w tym także Polska. Choć nie prowadzi się badań dedykowanych temu zjawisku, można jednak wnioskować, iż znaczna część polskiego społeczeństwa płaci wysokie rachunki za energię.

\section{Poziom ubóstwa energetycznego w Polsce}

Ubóstwo energetyczne jest problemem, który w różnym stopniu dotyczy wszystkich krajów członkowskich Unii Europejskiej. Jak wskazuje portal www.fuelpoverty.eu, zjawisko to w najmniejszym stopniu występuje w krajach najlepiej rozwiniętych (m.in. w Niemczech, Francji, Hiszpanii, krajach skandynawskich), w największym zaś na południu Europy (m.in. w Grecji i we Włoszech) oraz w krajach postkomunistycznych (m.in. w Estonii, Bułgarii, Rumunii, Polsce, na Węgrzech i Litwie).

Badania nad budżetem gospodarstw domowych wskazują, iż w 2015 r. wydatki związane z utrzymaniem mieszkania i nośnikami energii stanowiły drugą co do wielkości wartość w strukturze wydatków gospodarstw domowych (zaraz po żywności i napojach bezalkoholowych). Wynika $z$ tego, iż Polacy wydają ponad 1/5 swoich dochodów na ww. cele.

Te same badania, przeprowadzone przez Główny Urząd Statystyczny, wskazują, iż emeryci i renciści przeznaczają najwięcej na wydatki związane z utrzymaniem mieszkania lub domu i nośnikami energii - ponad 23\%, z czego same wydatki związane z nośnikami energii wynoszą wśród emery tów 14,4\%, a wśród rencistów 15,1\%. Pozostałe grupy (pracownicy, rolnicy i osoby prowadzące działalność gospodarczą) na analizowane wydatki przeznaczają mniej niż wynosi średnia ogólnopolska. 


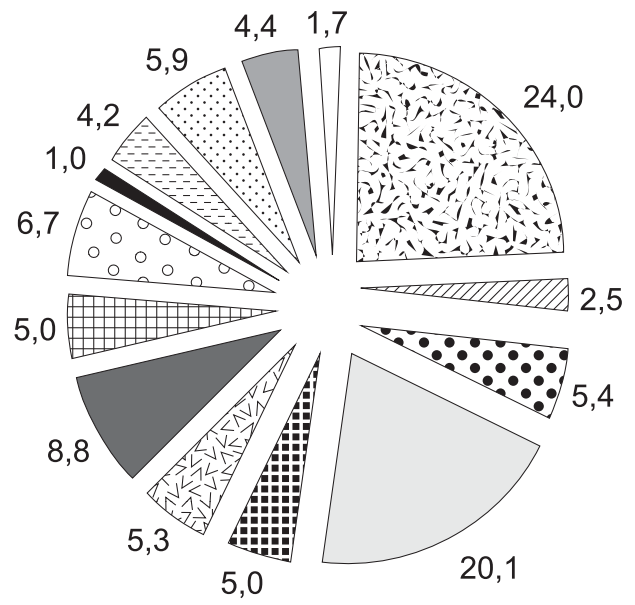
[N żywność i napoje bezalkoholowe
$\square$ napoje alkoholowe, wyroby tytoniowe
$\bullet$ odzież i obuwie
$\square$ użytkowanie mieszkania i nośniki energii
wyposażenie mieszkania i prowadzenie
I gospodarstwa domowego
Z zdrowie
$\square$ transport
四 łączność
$\square$ rekreacja i kultura
edukacja
- restauracje i hotele
pozostałe towary i usługi
wydatki pozostałe
kieszonkowe

Rycina 3. Struktura przeciętnych miesięcznych wydatków na 1 osobę w gospodarstwach domowych (w \% wydatków ogółem) w 2015 r.

Źródło: Budżet gospodarstw domowych w 2015 r., Warszawa 2016.

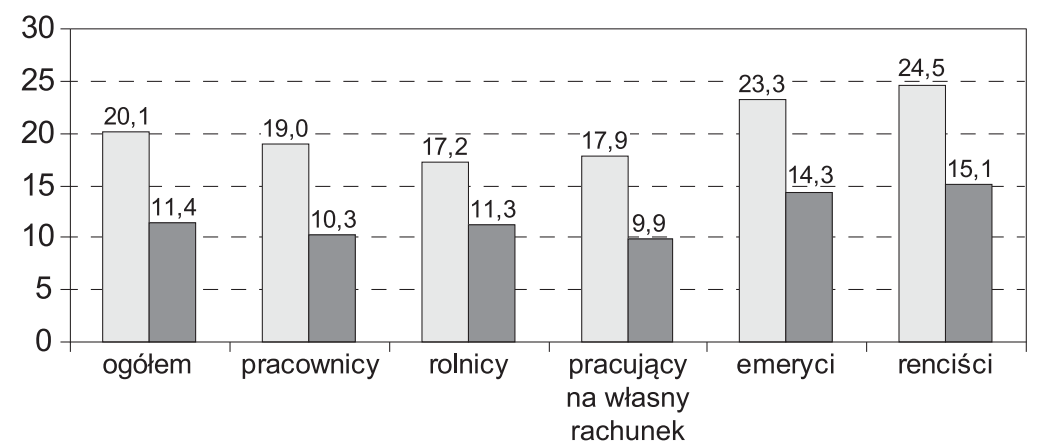

wydatki na utrzymanie mieszkania lub domu i nośniki energii w 2015 r.

w tym nośniki energii

Rycina 4. Udział przeciętnych miesięcznych wydatków (w \%) na 1 osobę związanych z utrzymaniem mieszkania lub domu i nośnikami energii w całości wydatków gospodarstw domowych według grup społeczno-ekonomicznych w 2015 r.

Źródło: Budżet gospodarstw domowych...

Warto zauważyć, iż wydatki na utrzymanie mieszkania, w tym wydatki na cele energetyczne, pozostają na względnie podobnym poziomie od ponad 10 lat i oscylują ok. 20\%. Widoczny ich spadek nastąił w roku 2007, jednakże trend ten nie utrzymał się, a od 2008 do 2011 następował systematyczny wzrost (do poziomu 20,6\% w roku 2011). Rok 2012 przyniósł niewielki (bo zaledwie o 0,4\%) spadek wydatków związanych z utrzymaniem mieszkania lub domu, a w roku 2013 nastąpił ich ponowny wzrost. Ostatnie dwa analizowane lata, tj. 2014-2015, wskazują, iż przeciętny miesięczny wydatek na osobę na utrzymanie mieszkania lub domu i nośniki energii stanowił 20,1\% całości wydatków gospodarstwa domowego. 


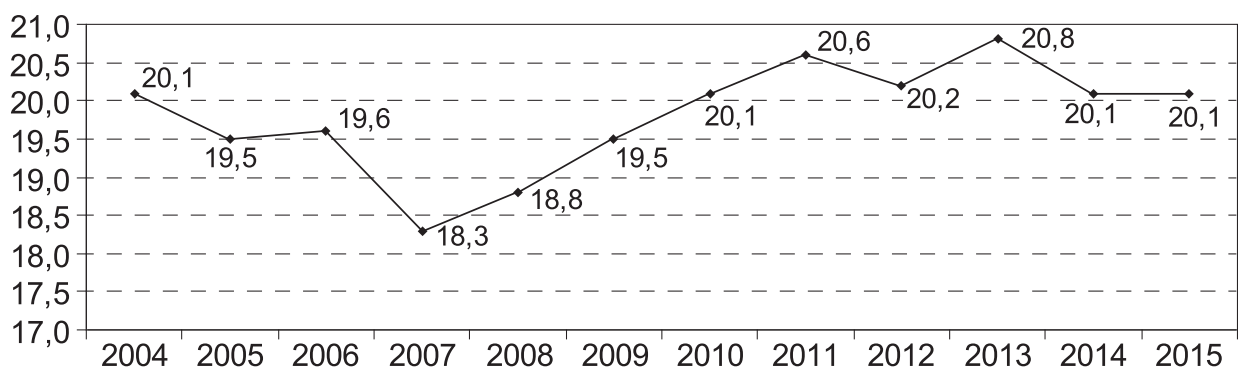

Rycina 5. Udział przeciętnych miesięcznych wydatków (w \%) na 1 osobę na utrzymanie mieszkania lub domu i nośniki energii w całości wydatków gospodarstw domowych w latach 2004-2015.

Źródło: Budżet gospodarstw domowych...

Przyjmując za punkt wyjścia absolutną definicję ubóstwa energetycznego, należy stwierdzić, że zjawisko to w 2013 r. dotknęło odpowiednio:

— przy założeniu progu 10\% dochodów: 44,4\% Polaków (tj. 17,2 mln osób),

— przy założeniu progu 13\%: 32,4\% Polaków (tj. 12,7 mln osób) ${ }^{11}$.

Grupami, które są najbardziej narażone na ubóstwo energetyczne w Polsce (w oparciu o definicję absolutną i próg 13\%), są: osoby prowadzące jednoosobowe gospodarstwa domowe (58\% jednoosobowych gospodarstw domowych), osoby utrzymujące się z renty (56\% tej grupy społecznej), osoby utrzymujące się ze świadczeń społecznych (48\% tej grupy). Problem ten dotyczy także w większym stopniu mieszkańców Polski wschodniej i południowej (przede wszystkim województwa podkarpackiego, świętokrzyskiego, lubelskiego, małopolskiego i podkarpackiego) oraz częściej osób mieszkających na wsi niż w dużych miastach ${ }^{12}$.

Poniższe wykresy, opracowane na podstawie danych Owczarka i Miazgi, prezentują skalę omawianego zjawiska w 2013 r. w różnych typach gospodarstw domowych.

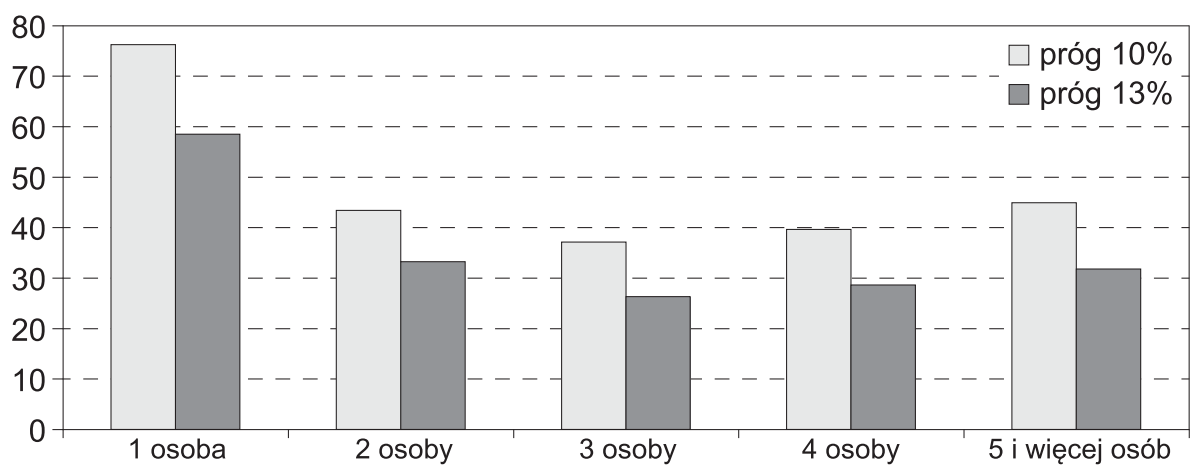

Rycina 6. Liczba osób w gospodarstwie domowym (w \%).

Źródło: opracowanie własne na podstawie danych: D. Owczarek, A. Miazga, Ubóstwo energetyczne w Polsce definicja i charakterystyka społeczna grupy, Warszawa 2015.

11 D. Owczarek, A. Miazga, op. cit., s. 26.

12 Ibidem, s. 27-31. 


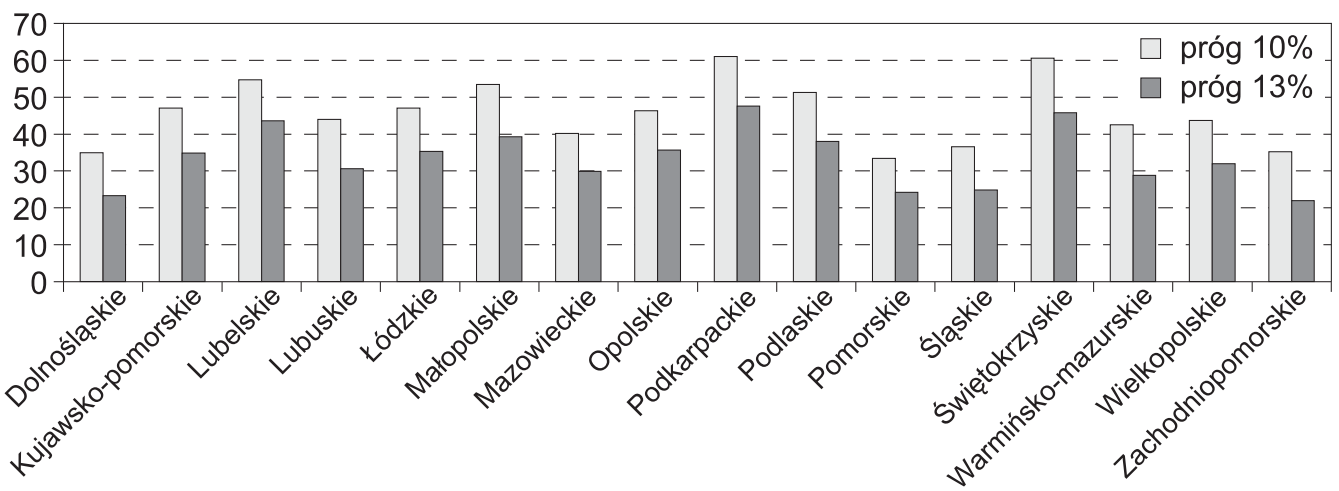

Rycina 7. Poziom ubóstwa energetycznego w Polsce (w \%).

Źródło: opracowanie własne na podstawie danych: D. Owczarek, A. Miazga, Ubóstwo energetyczne w Polsce definicja i charakterystyka społeczna grupy...

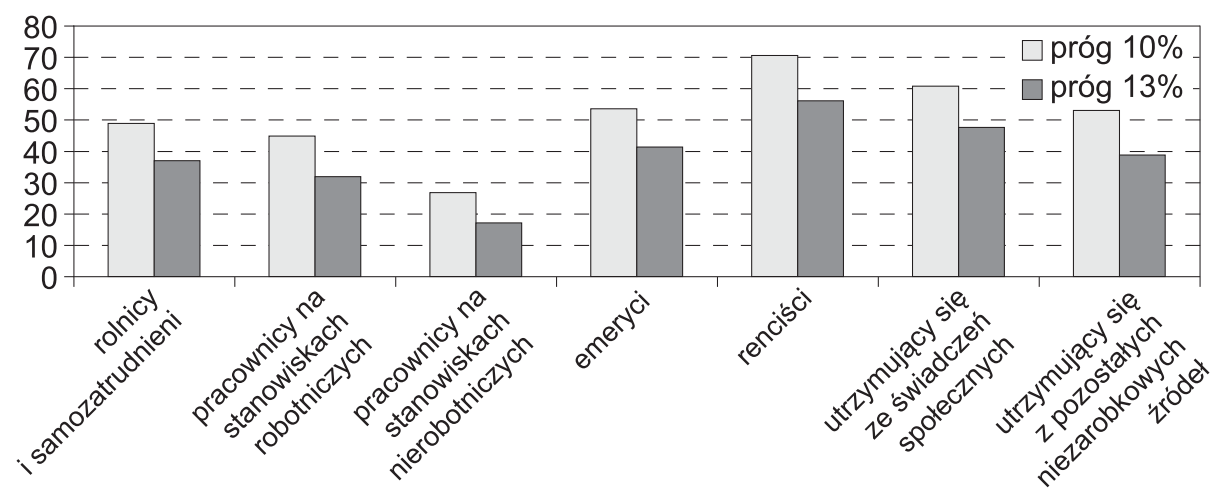

Rycina 8. Poziom ubóstwa energetycznego w podgrupach społeczno-ekonomicznych (w \%).

Źródło: opracowanie własne na podstawie danych: D. Owczarek, A. Miazga, Ubóstwo energetyczne w Polsce definicja i charakterystyka społeczna grupy...

W świetle definicji relatywnej poziomu ubóstwa energetycznego w 2013 r. problem ten dotyczył 17,1\% gospodarstw domowych w Polsce ${ }^{13}$. Jednakże bez względu na przyjętą metodologię określania skali tego zjawiska (czy to w oparciu o definicję absolutną i próg 10 lub $13 \%$, czy też na podstawie definicji relatywnej) poziom ubóstwa energetycznego w Polsce pozostaje wysoki i powinien być rozpatrywany w kategoriach problemu społecznego. Warto odnotować, iż ubóst wo energetyczne dotyczy nie tylko osób, które są ubogie ekonomicznie.

„Ubóstwo energetyczne opisywane zarówno za pomocą definicji absolutnej, jak i relatywnej charakteryzuje się niewielkim pokrywaniem się z ubóstwem dochodowym maksymalnie 30\% ubogich energetycznie jest także ubogich ekonomicznie"14. Wysokie rachunki za energię płacą także osoby, które mają relatywnie wysokie dochody, a miesz-

13 Ibidem, s. 35.

14 Ibidem, s. 50. 


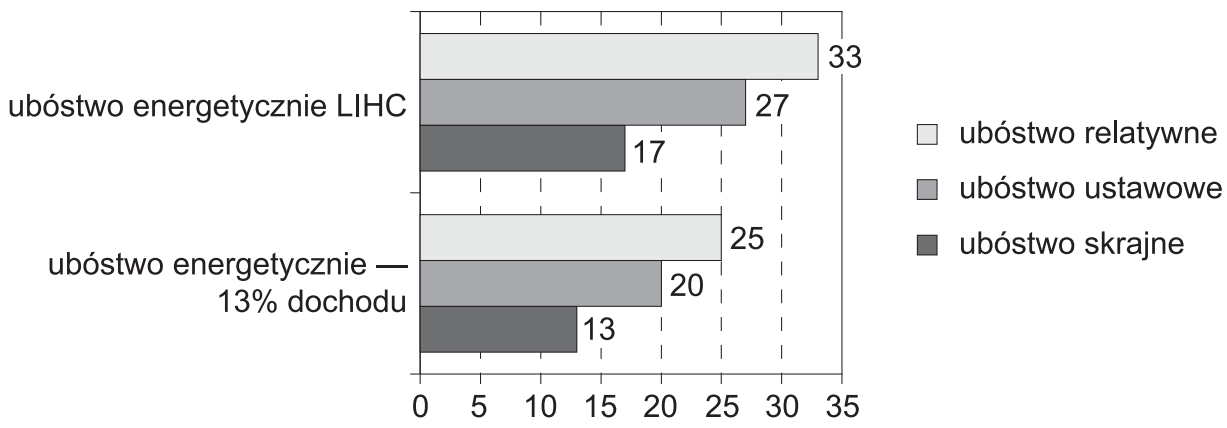

Rycina 9. Odsetek ubogich dochodowo w grupie ubogich energetycznie w Polsce w 2013 r. (w \%).

Źródło: D. Owczarek, A. Miazga, Ubóstwo energetyczne w Polsce - definicja i charakterystyka społeczna grupy..., s. 49.

kają w domach nieefektywnych energetycznie lub posiadają złe nawyki (np. w okresie grzewczym otwierają okna, nie zakręcając kaloryferów).

W najbliższych latach, według prognoz Owczarka i Miazgi ${ }^{15}$, ubóstwo energetyczne w Polsce będzie utrzymywało się na podobnym poziomie. Autorzy, po przeanalizowaniu czterech wymiarów zmian demograficzno-ekonomicznych (tj.: starzenia się społeczeństwa, zmian tkanki mieszkaniowej, zmian dochodów gospodarstw domowych oraz zmian cen energii), zauważyli, iż w perspektywie kolejnych kilkunastu lat odsetek ubogich energetycznie w Polsce jedynie nieznacznie spadnie.

Łączna realizacja scenariuszy w zakresie zmiany struktury demograficznej, budowy nowych budynków, wzrostu dochodów oraz cen prowadzi do wniosku, że ubóstwo energetyczne według miary względnej (LIHC) zmniejszy się z 15,3\% w 2015 roku do 14,9\% w roku 2030, a według miary subiektywnej zostanie ograniczone z 11,6\% do 10\%. Jednocześnie ubóstwo według miary absolutnej zwiększy się z 38,8\% do 42,9\% ${ }^{16}$.

Z uwagi na skalę ubóstwa energetycznego oraz prognozowany trend jego utrzymywania się na dotychczasowym poziomie nader ważne wydaje się niezwłoczne i kompleksowe podejście mające na celu wypracowanie mechanizmów wsparcia i przeciwdziałanie jego skutkom.

\section{Przeciwdziałanie ubóstwu energetycznemu w Polsce}

W Polsce, na szczeblu administracji rządowej, nie istnieje definicja ubóstwa energetycznego ani program przeciwdziałania temu zjawisku. W krajowych dokumentach strategicznych jedynie sygnalizuje się tę tematykę, jednakże dość ogólnikowo i nie implikuje to żadnych konkretnych działań.

Średniookresowa strategia Bezpieczeństwo Energetyczne i Środowisko - perspektywa do 2020 r. (BEiŚ), przyjęta uchwałą Rady Ministrów z dnia 15 kwietnia 2014 r. (uchwała

15 D. Owczarek, A. Miazga, Dynamiczne własności miar ubóstwa energetycznego, „IBS Research Report” 2016, nr 1, s. 3-4, http://ibs.org.pl/publications/dynamiczne-wlasnosci-miar-ubostwa-energetycznego/ (dostęp: 20.04.2017).

16 Ibidem, s. 17. 
nr 58, 2014), dotyczy dwóch obszarów, tj. energetyki i środowiska, oraz określa działania, jakie powinny być podjęte do $2020 \mathrm{r}$. Został w niej odnotowany problem ubóstwa energetycznego, jednakże kwestia ta została jedynie zasygnalizowana jako wymagająca dalszego rozpoznania i opracowania systemowego podejścia: „należy także dokonać rozpoznania w kraju zjawiska tzw. u b ó s t wa e n e r g e t y cz n e go i przystąpić do opracowania programu działań zmniejszających skalę tego zjawiska"17.

Także projekt Polityki energetycznej Polski do 2050 roku, wypracowany przez Ministerstwo Gospodarki w 2015 r., wskazuje na ubóstwo energetyczne jako jedno z uwarunkowań społecznych rozwoju polityki energetycznej. Jego przyczyn upatruje się w procesach starzenia się społeczeństwa oraz wzroście cen energii.

Jeżeli wysoka dynamika PKB nie będzie przyczyniać się do ograniczania stopy bezrobocia i podnoszenia dochodów ludności, przy rosnących cenach energii, można oczekiwać wzrostu odsetka GD znajdujących się w stanie ubóstwa energetycznego lub nim zagrożonych, co implikować będzie potrzebę ustanowienia odpowiednich instrumentów zaradczych i osłonowych ${ }^{18}$.

Najnowszy dokument strategiczny, Strategia na rzecz Odpowiedzialnego Rozwoju do roku 2020 (z perspektywa do 2030 r. . $^{19}$, dotyczący rozwoju społeczno-gospodarczego Polski, został przyjęty przez Radę Ministrów 14 lutego 2017 r. Wyznacza on główne kierunki rozwoju kraju, uwzględniając wymiar nie tylko gospodarczy, ale także społeczny (w tym problematykę spadku liczby osób w wieku produkcyjnym, starzenia się społeczeństwa, zmniejszenia się dzietności, migracji, ubóstwa, bezrobocia). Jednakże problem ubóstwa energetycznego nie znalazł się w kręgu zainteresowań projektodawców dokumentu. Stąd też można wnioskować, iż nadal władze Polski nie rozpatrują go w kategoriach jednego z kluczowych wyzwań społecznych.

Ustawa Prawo energetyczne wprowadza kategorię „odbiorcy wrażliwego”, czyli tego, któremu przysługuje dodatek energetyczny (zarówno na energię elektryczną, jak i gazową). Zmiana ta obowiązuje od 1 stycznia 2014 r. Decyzję o przyznaniu dodatku energetycznego wydaje wójt, burmistrz lub prezydent, na podstawie wniosku złożonego przez zainteresowaną osobę. Osoba, której przysługuje dodatek energetyczny, to taka, która otrzymała dodatek mieszkaniowy lub spełnia wszelkie przesłanki do jego uzyskania.

Zgodnie z ustawą z dnia 21 czerwca 2001 o dodatkach mieszkaniowych oraz Rozporządzeniem Rady Ministrów z dnia 28 grudnia 2001 r. dodatek mieszkaniowy przysługuje osobom, które spełniają poniższe warunki:

- Posiadają tytuł prawny do zajmowanego lokalu.

- Osiągają odpowiednio niskie dochody - sprawdzeniu zostaje poddany średni miesięczny dochód na jednego członka gospodarstwa domowego uzyskany w ostatnich trzech miesiącach. W przypadku gospodarstwa jednoosobowego nie powinien on przekraczać

17 Strategia „Bezpieczeństwo Energetyczne i Środowisko” — perspektywa do 2020 r., Warszawa 2017, s. 50, http://www.kigeit.org.pl/FTP/PRCIP/Literatura/008_3_Strategia_Bezpieczenstwo_Energetyczne_i_Srodowisko_2020.pdf (dostęp: 11.04.2016).

18 Polityka energetyczna Polski do 2050 roku, Warszawa 2015, s. 31, http://bip.me.gov.pl/node/24670 (dostęp: 11.04.2017).

19 Strategia na rzecz Odpowiedzialnego Rozwoju do roku 2020 (z perspektywa do 2030 r.), Warszawa 2017, https://www.mr.gov.pl/media/34298/SOR_2017_maly_internet_14072017_wstepPMM.pdf (dostęp: 15.04.2017). 
175\% kwoty najniższej emerytury (tj. 1544,48 zł); w gospodarstwie wieloosobowym jest to $125 \%$ tej kwoty (tj. 1103,20 zł).

- Posiadają odpowiednią powierzchnię lokalu, określoną zgodnie z liczbą osób wchodzących w skład danego gospodarstwa domowego, np. dla jednej osoby powierzchnia nie może przekraczać $45,50 \mathrm{~m}^{2}$; dla rodziny czteroosobowej jest to $71,50 \mathrm{~m}^{2}$.

Wysokość dodatku energetycznego określana jest corocznie w drodze obwieszczenia wydawanego przez ministra właściwego do spraw gospodarki, w terminie do 30 kwietnia każdego roku. Zgodnie z Obwieszczeniem Ministra Energii z dnia 22 kwietnia 2016 r. w sprawie wysokości dodatku energetycznego obowiązującego od dnia 1 maja 2016 r. do dnia 30 kwietnia 2017 r. stawka ta wynosiła odpowiednio:

- gospodarstwo domowe prowadzone przez osobę samotną - 11,29 zł/miesiąc;

- gospodarstwo domowe składające się z 2 do 4 osób - 15,68 zł/miesiąc;

- gospodarstwo domowe składające się z co najmniej 5 osób - 18,81 zł/miesiąc.

Najnowsze obwieszczenie z dnia 13 kwietnia 2017 r. nieznacznie zmniejszyło wysokości dodatku energetycznego, który był przyznawany od 1 maja 2017 r. do 30 kwietnia 2018 r. Stawki te wynosiły odpowiednio:

- gospodarstwo domowe prowadzone przez osobę samotną - 11,22 zł/miesiąc;

- gospodarstwo domowe składające się z 2 do 4 osób - 15,58 zł/miesiąc;

— gospodarstwo domowe składające się z co najmniej 5 osób - 17,80 zł/miesiąc.

Dane przedstawione na poniższym wykresie wskazują, iż wysokość dodatku energetycznego corocznie (od roku 2014, kiedy został on wprowadzony, do połowy roku 2018) ulega niewielkim zmianom w każdym $\mathrm{z}$ rodzajów gospodarstw domowych.

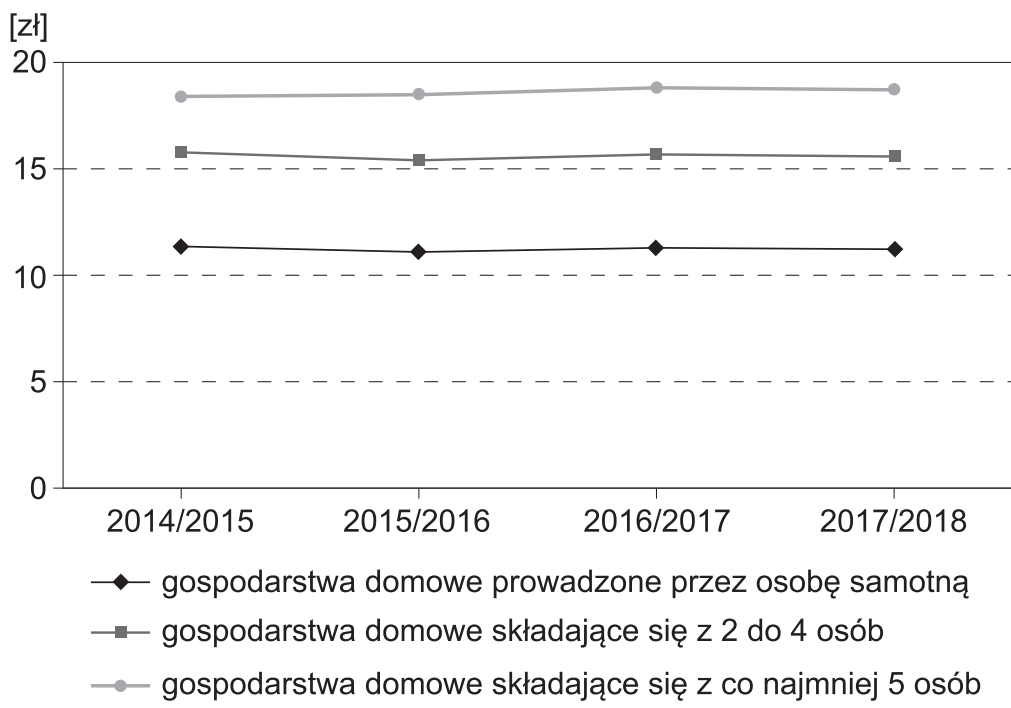

Rycina 10. Wysokość dodatku energetycznego w latach 2014-2018 w poszczególnych rodzajach gospodarstw domowych w Polsce (w PLN).

Źródło: opracowanie własne na podstawie obwieszczeń w sprawie dodatku energetycznego ${ }^{20}$.

20 Zestawienie zostało opracowane na podstawie obwieszczeń publikowanych w latach 2014-2017: Obwieszczenie Ministra Gospodarki z dnia 17 kwietnia 2014 r. w sprawie wysokości dodatku energetycznego 
Taka wysokość wsparcia finansowego nie rozwiąże problemu ubóstwa energetycznego w Polsce, może raczej stanowić jedynie symboliczną pomoc materialną dla rodzin najuboższych. Jednakże warto odnotować, iż problem ten został dostrzeżony na szczeblu krajowym, a pierwsze próby jego łagodzenia zostały podjęte.

\section{Podsumowanie}

Ubóstwo energetyczne jest realnym problemem, dotykającym znaczną grupę Polaków, jednakże w dalszym ciągu nie jest postrzegane w kategoriach problemu społecznego. Brak powszechnie obowiązującej definicji tego zjawiska, a także kompleksowych badań utrudnia jego dogłębne rozpoznanie. Zagadnienia te pozostają $\mathrm{w}$ kręgu zainteresowań wąskiej grupy badaczy, a przez decydentów są dostrzegane rzadko i traktowane marginalnie. W chwili obecnej nie istnieje żaden dokument na szczeblu strategicznym, krajowym, który byłby dedykowany zwalczaniu ubóstwa energetycznego. Jedynym instrumentem wsparcia jest dodatek energetyczny, który przydzielany jest przez ośrodki pomocy społecznej osobom spełniającym określone wymogi. Jednakże jego wysokość, corocznie określana ministerialnym obwieszczeniem, stanowi raczej symboliczną niż realną pomoc i nie może być efektywnym narzędziem wspierającym walkę z ubóstwem energetycznym. Ponadto dodatek energetyczny dedykowany jest wąskiej grupie odbiorców, osobom uprawnionym do korzystania $\mathrm{z}$ dodatku mieszkaniowego. Jak wskazują analizy, ubóstwo energetyczne nie pokrywa się z ubóstwem ekonomicznym, zatem ta forma wsparcia trafia jedynie do ograniczonej liczby osób, które borykają się z problemem zaspokojenia swoich potrzeb energetycznych.

Skala ubóstwa energetycznego oraz przewidywany poziom tego zjawiska w najbliższych kilkunastu latach wskazują, iż próby rozwiązania tego problemu powinny być podjęte na szczeblu rządowym. Jak sugeruje Aleksander Szpor, zagadnienie to powinno być przedmiotem prac międzysektorowego zespołu ekspertów:

Chociaż za problem ubóstwa energetycznego formalnie odpowiada Ministerstwo Rozwoju, to należałoby dążyć do przeniesienia tych kompetencji do Ministerstwa Rodziny, Pracy i Polityki Społecznej, lub do stworzenia silnego zespołu międzyresortowego współpracującego również z Ministrem Energii oraz Urzędem Regulacji Energetyki ${ }^{21}$.

Warto zwrócić także uwagę na ceny energii elektrycznej i cieplnej, które są jednymi z wyższych w krajach Unii Europejskiej. Polska energetyka, oparta przede wszystkim

obowiązującej od dnia 1 maja 2014 r. do dnia 30 kwietnia 2015 r.; Obwieszczenie Ministra Gospodarki z dnia 17 kwietnia 2015 r. w sprawie wysokości dodatku energetycznego obowiązującej od dnia 1 maja 2015 r. do dnia 30 kwietnia 2016 r.; Obwieszczenie Ministra Energii z dnia 22 kwietnia 2016 r. w sprawie wysokości dodatku energetycznego obowiązującej od dnia 1 maja 2016 r. do dnia 30 kwietnia 2017 r.; Obwieszczenie Ministra Energii z dnia 13 kwietnia 2017 r. w sprawie wysokości dodatku energetycznego obowiązującej od dnia 1 maja 2017 r. do dnia 30 kwietnia 2018 r.

21 A. Szpor, Ubóstwo energetyczne w Polsce - temat zastępczy czy realny problem?, „IBS Policy Paper” 2016, nr 2, s. 14, http://ibs.org.pl/publications/ubostwo-energetyczne-w-polsce-temat-zastepczy-czy-realnyproblem/ (dostęp: 15.03.2017). 
na krajowych surowcach węgla kamiennego i brunatnego, jest jedną z droższych i odbiegających od ogólnoeuropejskich trendów. Inwestycje w odnawialne źródła energii mogą wpłynąć na obniżenie kosztów energii i tym samym na zmniejszenie skali ubóstwa energetycznego w Polsce. Do 2020 r. celem strategicznym dla Polski (zgodnie z przyjętym paktem klimatyczno-energetycznym) jest zwiększenie wykorzystania zasobów energii ze źródeł odnawialnych, tak by jej udział w końcowym zużyciu energii brutto wyniósł $15 \%$ (w skali Unii Europejskiej wartość docelowa wynosi $20 \%$ ) $^{22}$. Zgodnie z polityką Unii Europejskiej oraz postulowanymi założeniami do realizacji do roku 2030 energia ze źródeł odnawialnych ma stanowić co najmniej $27 \%$ w całkowitym zużyciu energii. Trend ten pokazuje, iż Europa będzie dążyła do ograniczenia wykorzystywania zasobów naturalnych (w tym węgla i ropy) na rzecz rozwoju źródeł alternatywnych. Niedostosowanie się do wymogów unijnych może prowadzić do wzrostu cen energii elektrycznej i cieplnej. W przypadku niewypełnienia przez kraje członkowskie Unii Europejskiej celów pakietu klimatyczno-energetycznego można oczekiwać kar finansowych nakładanych przez Komisję Europejską.

\section{Bibliografia}

Budżet gospodarstw domowych w 2015 r., Główny Urząd Statystyczny, Warszawa 2016, http://stat.gov.pl/ obszary-tematyczne/warunki-zycia/dochody-wydatki-i-warunki-zycia-ludnosci/budzety-gospodarstw-domowych-w-2015-r-,9,10.html (dostęp: 9.03.2017).

Cutting the cost of keeping warm. A fuel poverty strategy for England, 3 marca 2015, http://www.infrastructure-intelligence.com/sites/default/files/article_uploads/cutting_the_cost_of_keeping_warm. pdf (dostęp: 4.04.2017).

Eurostat Newsrelease, 103/2016 - 27 maja 2016, http://ec.europa.eu/eurostat/documents/2995521/7405554/8 -27052016-AP-EN.pdf/b5652235-2df1-47ed-84c6-701614849b3a (dostęp: 12.04.2017).

Figaszewska I., Ubóstwo energetyczne - co to jest?, „Biuletyn Urzędu Regulacji Energetyki” 2009, nr 5, http://www.cire.pl/pliki/2/UbostwoenergetyczneFig.pdf (dostęp: 3.04.2017).

Frączek P., Konsekwencje przyjęcia pakietu energetyczno-klimatycznego dla przyszłej roli węgla kamiennego w polityce energetycznej Polski, http://ur.edu.pl/pliki/Zeszyt16/36.pdf (dostęp: 10.02.2017).

Miazga A., Owczarek D., Dom zimny, dom ciemny - czyli ubóstwo energetyczne w Polsce, „IBS Working Paper" 2015, nr 16, http://www.mpec.przemysl.pl/plugins/filemanager/userfiles/images/2015/pub/ubenerg.pdf (dostęp: 10.04.2017).

Obwieszczenie Ministra Energii z dnia 22 kwietnia 2016 r. w sprawie wysokości dodatku energetycznego obowiązującej od dnia 1 maja 2016 r. do dnia 30 kwietnia 2017 r., http://monitorpolski.gov.pl/ mp/2016/411/1 (dostęp: 11.04.2017).

Obwieszczenie Ministra Energii z dnia 13 kwietnia 2017 r. w sprawie wysokości dodatku energetycznego obowiązującej od dnia 1 maja 2017 r. do dnia 30 kwietnia 2018 r., http://www.monitorpolski.gov.pl/ MP/2017/394 (dostęp: 2.05.2017).

Obwieszczenie Ministra Gospodarki z dnia 17 kwietnia 2014 r. w sprawie wysokości dodatku energetycznego obowiązującej od dnia 1 maja 2014 r. do dnia 30 kwietnia 2015 r., http://isap.sejm.gov.pl/ DetailsServlet?id=WMP20140000291\&min=1 (dostęp: 1.01.2017).

22 P. Frączek, Konsekwencje przyjęcia pakietu energetyczno-klimatycznego dla przyszłej roli węgla kamiennego w polityce energetycznej Polski, http://ur.edu.pl/pliki/Zeszyt16/36.pdf, s. 445-447. 
Obwieszczenie Ministra Gospodarki z dnia 17 kwietnia 2015 r. w sprawie wysokości dodatku energetycznego obowiązującej od dnia 1 maja 2015 r. do dnia 30 kwietnia 2016 r., http://www.monitorpolski.gov. $\mathrm{pl} / \mathrm{mp} / 2015 / 377$ (dostęp: 1.05.2017).

Owczarek D., Miazga A., Dynamiczne własności miar ubóstwa energetycznego, „IBS Research Report” 2016, nr 1, http://ibs.org.pl/publications/dynamiczne-wlasnosci-miar-ubostwa-energetycznego/ (dostęp: 20.04.2017).

Owczarek D., Miazga A., Ubóstwo energetyczne w Polsce - definicja i charakterystyka społeczna grupy, Fundacja Instytut na rzecz Ekorozwoju, Warszawa 2015, http://www.chronmyklimat.pl/biblioteka/ ksiazki-raporty/ubostwo-energetyczne-definicja-i-charakterystyka-spoleczna-grupy+\&cd=1\&hl=pl $\& \mathrm{ct}=\mathrm{clnk} \& \mathrm{gl}=\mathrm{pl}($ dostęp: 4.04.2017).

Polityka energetyczna Polski do 2050 roku, Ministerstwo Gospodarki, Warszawa 2015, http://bip.me.gov. pl/node/24670 (dostęp: 11.04.2017).

Rozporządzenie Rady Ministrów z dnia 28 grudnia 2001 r., Dz.U. 2001, nr 156, poz. 1817, http://isap.sejm. gov.pl/DetailsServlet?id=WDU20011561817 (dostęp: 10.04.2017).

Ryś - termomodernizacja budynków jednorodzinnych, Narodowy Fundusz Ochrony Środowiska i Gospodarki Wodnej, http://nfosigw.gov.pl/oferta-finansowania/srodki-krajowe/programy-priorytetowe/ rys---termomodernizacja-budynko-jednorodzinnych/informacje-o-programie/ (dostęp: 1.05.2017).

Strategia „Bezpieczeństwo Energetyczne i Środowisko”- perspektywa do 2020 r., Ministerstwo Gospodarki, Ministerstwo Środowiska, Warszawa 2017, http://www.kigeit.org.pl/FTP/PRCIP/Literatura/008_3_Strategia_Bezpieczenstwo_Energetyczne_i_Srodowisko_2020.pdf (dostęp: 11.04.2016).

Strategia na rzecz Odpowiedzialnego Rozwoju do roku 2020 (zperspektywa do 2030 r.), Ministerstwo Rozwoju, Warszawa 2017, https://www.mr.gov.pl/media/34298/SOR_2017_maly_internet_14072017_wstepPMM. pdf (dostęp: 15.04.2017).

Szpor A., Ubóstwo energetyczne w Polsce - temat zastępczy czy realny problem?, „IBS Policy Paper” 2016, nr 2, http://ibs.org.pl/publications/ubostwo-energetyczne-w-polsce-temat-zastepczy-czy-realny-problem/ (dostęp: 15.03.2017).

The UK Fuel Poverty Strategy. 6th Annual Progress Report 2008. Fuel Poverty Statistics Annex, Department for Environment, Food and Rural Affairs, http://webarchive.nationalarchives.gov.uk/+/http:/www.berr. gov.uk/files/file48036.pdf (dostęp: 4.04.2017).

Ustawa z dnia 21 czerwca 2001 o dodatkach mieszkaniowych, Dz.U. z 2013 r., poz. 966, 984; z 2015 r. poz. 693,1220 ; z 2016 r., poz. 195, 1250, http://isap.sejm.gov.pl/DetailsServlet?id=WDU20130000966 (dostęp: 10.04.2017).

Węglarz A., Kubalski G., Owczarek D., Propozycje mechanizmów wsparcia procesu przeciwdziałania zjawisku ubóstwa energetycznego w Polsce, Fundacja Instytut na rzecz Ekorozwoju, Warszawa 2014, http:// www.chronmyklimat.pl/download.php?id=142 (dostęp: 12.04.2017).

\section{Energy poverty as a social problem and the ways of solving this issue}

Keywords: fuel poverty, sensitive recipient, energy

\section{Summary}

The article is devoted to one of the social problem - fuel poverty, that is difficulties with meeting energy needs. It provides the discretion of the issue, including the definitions which have been proposed by Brits and Poles. It also contains information about the scale of the problem in Poland in different social groups, identification of the reasons of fuel poverty as well as the possible ways of solving it. The analyses of Polish legal acts related to this issue has been conducted and described. 